\title{
RECOMMENDATIONS REGARDING HYPERGLYCAEMIA, BLOOD PRESSURE AND LIPID MANAGEMENT IN DIABETES MELLITUS - PRESENTATION OF KEY ASPECTS FROM THE 2019 ESC/EASD GUIDELINES ON DIABETES, PRE-DIABETES AND CARDIOVASCULAR DISEASES
}

\author{
Cosmin Mihai Vesa ${ }^{1}$, Amorin Popa ${ }^{1,2}$, Mihaela Popoviciu ${ }^{1,2}$, Loredana Popa ${ }^{2}$, \\ Mircea I. Popescu ${ }^{1,2}$, Monica Sabău $u^{1,2}$, Lucia Daina ${ }^{1,2}$, Gheorghe Carp ${ }^{1,2}$ \\ ${ }^{1}$ Faculty of Medicine and Pharmacy, University of Oradea, 410073 Oradea, Romania \\ ${ }^{2}$ Clinical County Emergency Hospital of Oradea, 410169 Oradea; Romania \\ Corresponding author: Vesa Cosmin Mihai, E-mail:v_cosmin_15@yahoo.com
}

\begin{abstract}
The purpose of our review is to bring to the clinical specialities physicians' attention the recommendations regarding diabetes mellitus (DM) management presented in the 2019 ESC/EASD Guidelines on diabetes, pre-diabetes and cardiovascular diseases. Key aspects from the guideline regarding blood pressure, lipid and glucose modern management are presented with focus of reducing cardiovascular risk in diabetes mellitus patients. The clinician must not forget that every DM patient is a candidate for a future cardiovascular event and that multifactorial and patient-adapted therapy is the key approach in reducing this risk.
\end{abstract}

Keywords: diabetes management guideline, hypertension, dyslipidaemia, cardiovascular risk.

\section{Rezumat}

Scopul acestei lucrări este de a aduce în atenția clinicienilor recomandările privind managementul modern al diabetului zaharat prezentate în ghidul publicat în anul 2019 ca urmare a consensului Societatății Europene de Cardiologie și Asociației Europene de Studiu a Diabetului. Aspecte cheie din ghid vizând managentul valorilor tensionale, lipidelor serice și hiperglicemiei sunt prezentate, accentul căzând asupra reducerii riscului cardiovascular. Clinicianul nu trebuie să uite că fiecare pacient diabetic este un candidat pentru un viitor eveniment cardiovascular și că terapia multifactorială și adaptată pacientului este esențială pentru reducerea acestui risc.

Cuvinte cheie: ghid de management al diabetului zaharat, hipertensiune arterială, dislipidemie, risc cardiovascular. 


\section{INTERNAL}

\section{General Reviews}

\section{Introduction}

The current review aims to present the most important new aspects regarding the clinical management in DM and pre-DM patients according to the 2019 ESC/EASD Guidelines on diabetes, pre-diabetes and cardiovascular diseases in order for better treatment of the affected individuals.

\section{Risk stratification}

One of the most important concepts in the 2019 ESC/EASD guideline compared to the 2013 ESC/EASD guideline $^{(2)}$ is the cardiovascular risk stratification of DM patients, this classification has been adapted after the cardiovascular risk stratification defined in the 2016 ESC Guidelines on CVD prevention in clinical practice ${ }^{(3)}$.

DM patients are classified in three categories of cardiovascular risk from moderate to very high $^{(1)}$. The classification is based on the presence of cardiovascular events in the medical history, the presence of target organ damage, the presence of cardiovascular risk factors and DM duration ${ }^{(1)}$.

This classification will further impact the therapeutic decision for these patients and in our opinion the most important aspect is that a DM patient needs to be properly evaluated from medical history to biochemical examinations and imagistic examinations in order to establish the correct cardiovascular risk. The 2019 guide gives high importance to detection of target organ damage in DM patients, therefore the screening for microalbuminuria (class I, level B recommendation) ${ }^{(1)}$, resting ECG (class I, levels $B$ recommendation) ${ }^{(1)}$, determination of carotid or femoral atherosclerotic plaque (class Ila, level $\mathrm{B})^{(1)}$ or determination of coronary artery calcium score (class Ilb, level $B$ recommendation $)^{(1)}$ can bring further information to the clinician for an accurate diagnosis of the cardiovascular risk.

\section{Blood pressure management}

Hypertension is highly prevalent in T2DM patients ${ }^{(4)}$ with severe consequences on the cardiovascular system such as development of ischemic heart disease and heart failure ${ }^{(5)}$. Compared with the older 2013 ESC/EASD guideline new blood pressure targets have been established.

The 2013 ESC/EASD diabetes guideline established a blood pressure target of $<140 / 85$ mmHg. In the new 2019 guideline the idea is to personalize the blood pressure target according to the patients age and pathology. Optimal systolic blood pressure target for DM patients according to the 2019 consensus is $130 \mathrm{mmHg}$ (class A recommendation) ${ }^{(1)}$. The guideline specifies that a target of systolic blood pressure $<130$ 

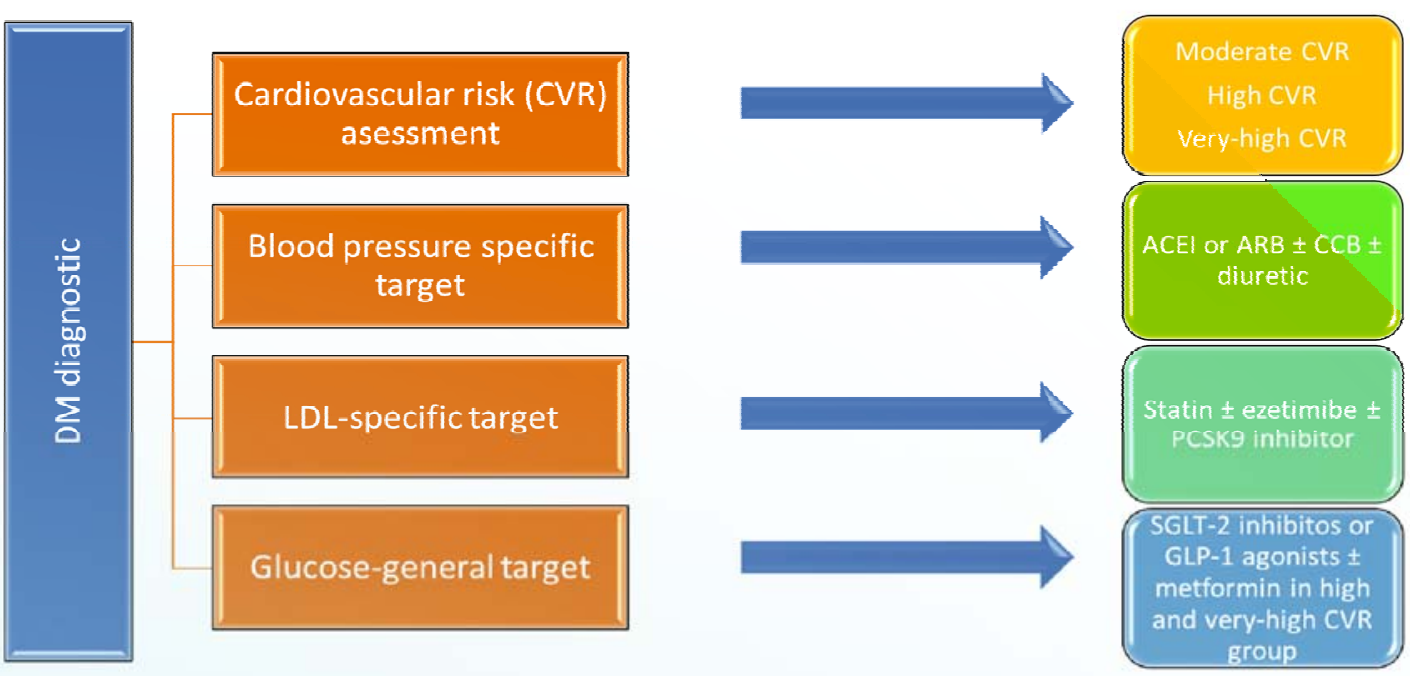

Figure 1. Summary of recommendations for management of DM patients in the moment of diagnostic after the information provided in reference (1)

$\mathrm{mmHg}$ can be set as goal if the patient tolerates it well, because an additional benefit can be achieved in cerebrovascular disease prevention.

Also, a reduction of systolic blood pressure $<120 \mathrm{mmHg}$ is not recommended (class $\mathrm{A}$ recommendation $)^{(1)}$. The 2019 guideline recommends a reduction of diastolic blood pressure to $<80 \mathrm{mmHG}$ but not $<70 \mathrm{mmHG}$

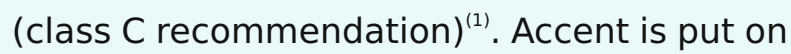
modification of lifestyle in pre-DM or DM and includes weight loss, reducing the salt intake, consumption of fruits and vegetables, consumption of low-fat dairy products. According to the 2019 guideline blood pressure should be treated at values $\geq 140 / 90$ $\mathrm{mmHG}^{(1)}$. Concerning the recommended drugs for treatment ACEI or ARB are the firstline recommended agents, when the first agent is not enough for blood pressure reduction a combination between an ACEI or ARB and a calcium channel blocker or diuretic should be used ${ }^{(1)}$.

\section{Dyslipidaemia management}

More than $60 \%$ of type 2 DM patients have dyslipidaemia, the characteristic of lipid profile being high triglycerides, low HDLcholesterol, high values of VLDL and IDL and as a consequence high non-HDL cholesterol $^{(6)}$; LDL-cholesterol levels are moderately increased or normal but the characteristic is the predominance of small dense LDL-cholesterol particles ${ }^{(6)}$. In the sector of lipid management of DM patients, we can observe the importance of cardiovascular risk categories in DM patients. LDL-cholesterol targets are correlated according to cardiovascular risk category. A target of LDL-cholesterol $<100 \mathrm{mg} / \mathrm{dL}$ is recommended for DM patients with moderate cardiovascular risk, a target of LDLcholesterol $<70 \mathrm{mg} / \mathrm{dL}$ for those in the highrisk category and $<55 \mathrm{mg} / \mathrm{dL}$ for the very high-risk category ${ }^{(1)}$. Compared with the 2013 ESC/EASD guideline the LDL-cholesterol 


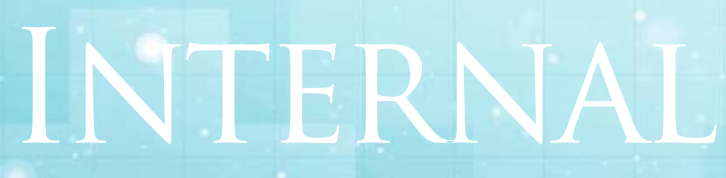

General Reviews

target was lowered, in the 2013 guideline LDL target was $<100 \mathrm{mg} / \mathrm{dL}$ for the high cardiovascular risk category and $<70 \mathrm{mg} / \mathrm{dL}$ for very high-risk category risk ${ }^{(2)}$. Therefore, patients with history of cardiovascular events such as acute coronary syndrome or stroke that automatically belong to the very highrisk category should attain, according to the new guideline, a very demanding target of LDL cholesterol of $<55 \mathrm{mg} / \mathrm{dL}^{(1)}$.

Statins obviously remain the first-choice agents for LDL-cholesterol reduction because of the numerous trials that demonstrated their efficacy in reducing cardiovascular risk, if the LDL-cholesterol goal is not attained ezetimibe can be added to the lipid-lowering therapy ${ }^{(1)}$. Alirocumab and evolocumab are PCSK9 inhibitors, which can be included in the treatment panel in patients with statin and ezetimibe combination who do not reach the LDL-cholesterol targets or in patients with statin intolerance ${ }^{(1)}$. Evolocumab in FOURIER trial $^{(7)}$ and alirocumab in ODYSSEY OUTCOMES trial $^{(8)}$ have demonstrated their role in reducing LDL-cholesterol and the risk of cardiovascular composite outcome (myocardial infraction, stroke, cardiovascular death) and have been included in the ESC/EASD guideline as add-on agents in lipidlowering therapy with a class I level B recommendation $^{(1)}$. In patients with high serum triglycerides and low HDL-cholesterol the use of fibrates in indicated ${ }^{(1)}$.
NOT ONLY Hyperglycaemia management - need for glucose-lowering therapies with cardiovascular risk reduction

The glucose control target recommended in the ESC/EASD 2019 guideline is represented by an $\mathrm{HbAlc}<7 \%{ }^{(1)}$, that has a proven role for reducing microvascular DM complications such ad diabetic retinopathy or neuropathy, but a non-statically significant role in reducing macrovascular events in DM patients ${ }^{(9)}$. In order to prevent cardiovascular events multifactorial approach is essential ${ }^{(9)}$. The revolution in DM management occurred when novel glucose-lowing drugs appeared that not only improve glycaemic control but also reduce the risk of cardiovascular events because of their multiple effects on metabolism, blood pressure or body weight. The use of glucose lowering drugs with proven cardiovascular benefit is recommended in the presence of atherosclerotic cardiovascular disease ${ }^{(1)}$. The most prominent drugs with such capabilities are SGLT-2 inhibitors and GLP-1 agonists ${ }^{(10)}$.

Our opinion is that is important to popularize and present in this context the pleiotropic proprieties of SGLT-2 inhibitors and GLP-1 agonists in order to popularize among physicians their multiple benefits. The two classes share common action mechanisms for cardiorenal protection and specific action mechanisms. Their common effects are 
represented by: reduction of blood glucose, reduction of body weight, reduction of blood pressure, decrease of visceral fat, improvement of lipid profile ${ }^{(10)}$. The specific effects of SGLT-2 such as empagliflozin, dapagliflozin or canagliflozin include natriuresis, reduction of intraglomerular pressure, reduction of interstitial oedema, shift of metabolism to fatty acid utilisation with better cardiac performance, erythropoiesis with better delivery of oxygen to tissues, reduction of albuminuria and preservation of glomerular filtration rate ${ }^{(11)}$. Because of their specific hemodynamic effects, SGLT-2 play a special role in DM patients with heart failure, the ESC/EASD 2019 guideline recommends, class I level A recommendation, their use in DM patients for their capability to significantly reduce heart failure hospitalisation rate ${ }^{(1)}$. The specific effects of GLP-1 agonists such as liraglutide, semaglutide, dulaglutide or exenatide are reduction of pro-inflammatory molecules levels, anti-atherosclerotic effect, antioxidant effect, reduction of $\beta$-cell apoptosis rate, decrease of appetite and neuroprotection $^{(12)}$.

Based on their properties and their very good results from cardiovascular outcome trials (CVOTs) regarding cardiorenal protection, our opinion is that the current ESC/EASD 2019 guideline makes a very important step compared to American Diabetes Association (ADA) Standard of Care 2020 guideline: if the patient has atherosclerotic cardiovascular disease or the cardiovascular risk stratifications places him in the high or very high risk category in the moment of DM diagnostic the use of SGLT-2 inhibitors or GLP1 agonists is recommended before metformin (1). ADA 2020 guideline recommends metformin as first drug of choice and the SGLT-2 inhibitors or GLP-1 agonist is added to metformin if the patients has established atherosclerotic cardiovascular disease, heart failure or chronic kidney disease ${ }^{(13)}$. Although at first glance it may seem that DM patients rapidly benefit from the same treatment, metformin and SGLT-inhibitor or GLP-1 agonist, in clinical practice there is the risk of clinical inertia, if a patient with high or very high cardiovascular risk is given metformin as first-choice drug and he achieves good blood glucose control the physician can keep him on metformin until his glycaemic worsen and only then add and SGLT-2 inhibitor or GLP-1 agonist.

\section{Conclusion}

The most important novelty from the 2019 ESC/EASD Guidelines on diabetes, prediabetes and cardiovascular diseases is the cardiovascular risk stratification of DM patients and an immediate adaptation of blood pressure, lipid, glucose targets and glucose-lowering therapies to his category of risk. Since most DM patients belong to the high or very high-risk cardiovascular risk category our opinion is that these patients will greatly benefit from these novel recommendations.

Conflict of interest: None to declare. Funding: None.

\section{References}

1. Cosentino F, Grant PJ, Aboyans V, et al. 2019 ESC Guidelines on diabetes, pre-diabetes, and cardiovascular diseases developed in collaboration with the EASD. Eur Heart J. 2020;41(2):255-323. doi:10.1093/ eurheartj/ ehz486

2. Ryden L, Grant PJ, et.al. ESC Guidelines on diabetes, pre-diabetes, and cardiovascular diseases developed in collaboration with the EASD: The Task Force on diabetes, pre-diabetes, and cardiovascular diseases of the European Society of Cardiology (ESC) and developed in collaboration with the European Association for the Study of Diabetes (EASD). Eur HeartJ 2013;34:30353087 


\section{INTERNAL}

\section{General Reviews}

3. Piepoli MF, Hoes AW, et.al ;ESC Scientific Document Group. 2016 European Guidelines on cardiovascular disease prevention in clinical practice: The Sixth Joint Task Force of the European Society of Cardiology and Other Societies on Cardiovascular Disease Prevention in Clinical Practice (constituted by representatives of 10 societies and by invited experts )Developed with the special contribution of the European Association for Cardiovascular Prevention \& Rehabilitation (EACPR). Eur HeartJ 2016;37:23152381.

4. Centers for Disease Control and Prevention. National Diabetes Statistics Report, 2017. Atlanta, GA: Centers for Disease Control and Prevention, U.S. Dept of Health and Human Services; 2017.

5. Tatsumi Y, Ohkubo T. Hypertension with diabetes mellitus: significance from an epidemiological perspective for Japanese. Hypertens Res. 2017 Sep;40(9):795-806. doi: 10.1038/hr.2017.67. Epub 2017 Jul 13. PMID: 28701739.

6. Ginsberg HN, MacCallum PR. The obesity, metabolic syndrome, and type 2 diabetes mellitus pandemic: Part I. Increased cardiovascular disease risk and the importance of atherogenic dyslipidemia in persons with the metabolic syndrome and type 2 diabetes mellitus. J Cardiometab Syndr. 2009;4:113-119.

7. Sabatine MS, Giugliano RP, Keech AC, Honarpour N, Wiviott SD, Murphy SA, Kuder JF, Wang H, Liu T, Wasserman SM, Sever PS, Pedersen TR; Fourier Steering Committee and Investigators. Evolocumab and clinical outcomes in patients with cardiovascular disease. N Engl
J Med 2017;376:17131722.

8. Schwartz GG, Steg PG, Szarek M, Bhatt DL, Bittner VA, Diaz R, Edelberg JM, Goodman SG, Hanotin C, Harrington RA, Jukema JW, Lecorps G, Mahaffey $K W$, Moryusef A, Pordy R, Quintero K, Roe MT, Sasiela WJ, Tamby JF, Tricoci P, White HD, Zeiher AM; Odyssey Outcomes Committees and Investigators. Alirocumab and cardiovascular outcomes after acute coronary syndrome. N EnglJ Med 2018;379:20972107.

9. Huang D, Refaat M, Mohammedi K, Jayyousi A, Al Suwaidi J, Abi Khalil C. Macrovascular Complications in Patients with Diabetes and Prediabetes. Biomed Res Int. 2017;2017:7839101. doi:10.1155/2017/7839101

10. Nagahisa T, Saisho Y. Cardiorenal Protection: Potential of SGLT2 Inhibitors and GLP-1 Receptor Agonists in the Treatment of Type 2 Diabetes. Diabetes Ther. 2019;10(5):1733-1752. doi:10.1007/s13300-01900680-5

11. Patel DK, Strong J. The Pleiotropic Effects of SodiumGlucose Cotransporter-2 Inhibitors: Beyond the Glycemic Benefit. Diabetes Ther. 2019;10(5):1771-1792. doi:10.1007/s13300-019-00686-z

12. Yamagishi S, Matsui T. Pleiotropic effects of glucagonlike peptide-1 (GLP-1)-based therapies on vascular complications in diabetes. Curr Pharm Des. 2011 Dec; 17(38):4379-85. doi: 10.2174/ 138161211798999456. PMID: 22204436.

13. American Diabetes Association, Standards of Medical Care in Diabetes-2020. Diabetes Care 2020;43(Suppl. 1) 